\title{
DEVELOPING ENGLISH READING TEXTBOOK OF PROCEDURE TEXT FOR GRADE XI OF AVIATION MANAGEMENT VOCATIONAL SCHOOL
}

\author{
AN ARTICLE \\ Submitted in Partial Fulfillment of the Requirements \\ for the Degree of Sarjana Pendidikan
}

By:

DIAN REGINA

Registration Number: 2133121023

\section{ENGLISH AND LITERATURE DEPARTMENT FACULTY OF LANGUAGES AND ARTS STATE UNIVERSITY OF MEDAN} 2018 
ARTIKEL

DEVELOPING ENGLISH READING TEXTBOOK OF PROCEDURE TEXT FOR GRADE XI OF AVIATION MANAGEMENT VOCATIONAL SCHOOL

Disusun dan Diajukan oleh:

Dian Regina

NIM. 2133121023

Telah diverifikasi dan dinyatakan memenuhi syarat untuk diunggah pada jurnal online

Medan, Januari 2018

Menyetujui

Dosen Pembimbing I

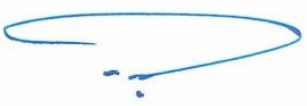

Dra. Masitowarni Siregar, M.Ed.

NIP. 196711021993032001
Dosen Pembimbing II

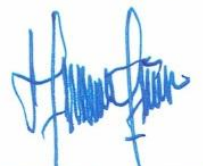

Tiarnita M.S. Bł. Siregar, S.Pd., M.Hum.

NIP. 198208112008012005

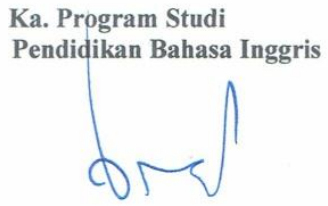

Nora Ronita Dewi, S.Pd., S.S., M.Hum.

NIP. 198005222008122003 


\title{
DEVELOPING ENGLISH READING TEXTBOOK OF PROCEDURE TEXT FOR GRADE XI OF AVIATION MANAGEMENT VOCATIONAL SCHOOL
}

\author{
* Dian Regina \\ **Masitowarni Siregar \\ **Tiarnita Maria Sarjani Br. Siregar
}

\begin{abstract}
Regina, Dian. Registration Number : 2133121023. Developing English Reading Textbook of Procedure Text for Grade XI of Aviation Management Vocational School. A Thesis. English Educational Program. State University of Medan, 2018.

The study aims to make an appropriate English reading textbook for grade XI students of aviation management vocational school, Medan. This study was conducted by applying the six phases of educational research and development proposed by Borg and Gall which are 1) Gathering information and data, 2) Analyzing data, 3) Developing Procedure Text Materials, 4) Validating new procedure text materials by expert, 5) Revising reading procedure text materials based on experts' suggestions, and 6) Final Products (Reading Procedure Text Textbook). It was found that students and teacher agreed that the existing materials currently used by the students were irrelevant with aviation management's students. The irrelevance materials were then developed by applying the ESP approach. The texts were developed into five new relevant procedure text materials. The new materials were validated by two experts. The average score of the validation was 4.6. It showed that the new procedure text materials were very good, relevant, and feasible.
\end{abstract}

Keywords: English for Aviation Management, Procedure Texts

* Graduate

** Lecturer 


\section{INTRODUCTION}

\section{Background of the Study}

English is one of the compulsory subjects in Indonesia education as a foreign language. Reading is one of the four language skill besides listening, writing, and speaking which should be mastered by student in learning English. Reading is defined as the ability to draw meaning from the printed page and interpret this information appropriately (Grabe and Stoller, 2002). Selecting a reading text for student is very important in the learning of reading. To read such a text contains familiar background will build more interest in student at reading process. As stated by Blagojevic (2013) that student will understand texts much better if the texts are written with points of view students have already become familiar.

In Indonesia, there are two kinds of secondary schools which are differentiate based on the needs and interests, those are general secondary school (SMA) which is focuses on knowledge expansion and skills improvement of student, and preparing student for further education, and vocational secondary school (SMK) which is focuses on development of skill that apply to a certain specific occupation, and preparing students for employment as well as developing professional attitude. Considering this fact, the materials given to the two kinds of school should be differentiated based on the needs and major as well, including the text materials.

Aviation management vocational school is one of many kinds of major that we could find in Indonesia for secondary school. It is an expertise program that aims to equip 
students with the skills, knowledge, and attitudes to be competent in handling the things around the airport also in the middle of flight.

Thus, the reading text given to such school should relate to the aviation because their needs in relation to their major are the things around the aviation field. It is also includes the example of procedure text given to them. Based on Schoolbased Curriculum (KTSP), procedure text is one of the types of reading text learnt by the eleventh grade students of vocational secondary school. It can be seen from one of the basic competencies of English subject, stated in syllabus:

\subsection{Memahami instruksi-instruksi sedderhana}

As stated by Blagojevic (2013), the suitable procedure text will motivate students in reading because they are truly motivated to study only if the teaching materials constantly address their need that is aviation. The adaptation of reading texts to be related to the students' needs and major is actually the application of English for Specific Purpose (ESP). As stated by Richards (2001) that the concern to make language courses more relevant to students' needs leads this period to the emergence of ESP.

However, based on the observation through interviewing the English teacher of Aviation Management Vocational School Medan grade XI on Tuesday, April $18^{\text {th }}$ 2017, it was found that the materials provided in the text book are not appropriate and suitable with the major. The materials including the reading texts are considered unsuitable for the students because they do not meet the needs or the purposes of the 
students are to study in relation to their major. Thus, it is contrary to the theory of ESP that the materials are expected to be relevant to the students. This school currently uses the textbook provided by Ministry of National Education which presented in e-book version. The teacher said, "The materials provided in the textbook are not specified for Aviation Management Vocational School. As we know that most of the terms used in the Aviation are presented in English. The terms that are used in the Aviation are different with the general English, mean while, the book that is provided by the school contains the general materials which are more suitable to general school.

\section{REVIEW OF LITERATURE}

Learning materials are the core of the learning activity that facilitate the students to achieve their goals and success in learning language, it can be from audio cassettes, videos, dictionaries, workbooks, photocopied exercises, newspaper, photographs, task written on cards, etc (Tomlinson, 2012).

Based on Hutchinson and Waters (1987), ESP is an approach to language learning that is based on learners need. The content and method making are based on the learners' reason for learning. So, as the preceding description shows that Flight Management Vocational school students have different purposes in learning English unlike regular high school students.

Hutchinson and Waters (1987) state that "ESP is an approach to language teaching in which all decisions as to content and method are based on the learner's 
reason for learning". ESP has characteristics in which the teaching and learning concern on how students can meet the specific needs they want to learn (Anthony, 1997).

\section{RESEARCH METHODOLOGY}

\section{Research Design}

The research was conducted based on educational Research and Development $(\mathrm{R} \& \mathrm{D}) . \mathrm{R} \& \mathrm{D}$ is one of research design aimed at developing and validating educational products, like curriculum, syllabus, textbooks, instructional media, modules, assessment instrument, etc. (Borg \& Gall, 1985).

\section{Data and Source of Data}

The first data of this study was the existing material of procedure text and the source of data was the book used in the aviation management vocational school grade XI. The next data was the result of the students' need analysis and the source of data were the students of aviation management vocational school grade XI which is consisted of 20 students. The last data was the result of the interview to support the previous information and the source of data was the English teacher in aviation management vocational school.

\section{The Instrument of Data Collection}

The data was collected through the analysis of questionnaire and interviews, and also the documents such as syllabus and the textbook used in the school. The data used in this study are the questionnaires; it was administered to the students to gather 
data about students' needs in terms of their necessities, lacks, and wants. The next data is the result of the interview session that was held to the teacher as the instructor and controller of learning process in the classroom. It was done to support the data from the questionnaire. The last data is documents such as existing materials or textbook and syllabus which had function as the tools to collect the data.

\section{Techniques of Analyzing the Data}

The data was analyzed to get the solution of students' problems and appropriate reading materials based on students needs. Then, this data is used to develop new reading materials.

The data were analyzed as follows:

1. Analyze the students' needs by using the questionnaires and interview. This data were needed to evaluate the existed reading materials and the appropriate materials based on students' need.

2. The result from questionnaires and interview would be analyzed, then plan the relevant reading materials, particularly procedure text.

\section{MATERIAL DEVELOPMENT}

As this research adapting Borg and Gall's research theory (1985), they proposed 6 steps of $\mathrm{R} \& \mathrm{D}$ cycle, as follows:

1. Gathering information from Aviation Management Vocational School Medan about the learning activity and environment. The data were taken 
from questionnaires that will be administered to the students and the interview with the teacher.

2. Analyzing the students' needs and existing materials based on the data and information.

3. Designing reading materials based on students' need. The designing reading material in the form of textbook was done by selecting or adapting other materials that is more suitable with the needs from some sources such as books or internet. The selected descriptive text materials then were adapted based on the principles of materials development in order to present well organized suitable procedure text materials.

4. Evaluating or validating the new material by the experts. In this case, experts were English subject teacher and lecturer. The teacher and the lecturer were given a questionnaire in order to assess the appropriateness of the texts in terms of linguistic, process, content, and layout.

5. Revising reading material based on experts' suggestion.

6. Revised-developing reading materials (final products), fixing the final of the developed product in order to produce the final product by the experts.

\section{FINDINGS}

\section{Gathering Information and Data}

Gathering information and data was the first step in developing suitable materials. The information and data were taken by doing the observation, 
interviewing the English teacher and distributing the questionnaires to the students of eleventh grade of UPW class.

From the observation, there were found some information and data, they are: curriculum, syllabus, existing materials that is the English textbook. The next step after having the observation done was conducting the need analysis. It was done by administering the questionnaire to the students and doing the interview to the English teacher to gather more detail data about the needs of aviation management students so that, the suitable procedure text materials for reading skill could be identified.

\section{Analyzing the Data}

The main data of this study were the existing materials which is the English reading textbook of procedure text for grade XI of aviation management vocational school and the students' need. The existing materials were matched to the students' needs to identify whether the existing materials meet the students' need or not. After that, the analysis of the students' need became the guidance for the researcher in developing suitable procedure text materials for reading skill.

It was found that the school used the English textbook published by the Ministry of Education and Culture "Effective Communication: An Integrated Course of English for Vocational High School 2nd year SMK" (Appendix F). The book provided some procedure texts, namely: "How to Use the Facsimile Machine", "How to Make a Yummy No-Bake Cherry Cheese Cake", and "How to Get Your Car Out of the Mud". These texts were considered not suitable to the aviation management's 
students because it didn't meet the needs or the purposes of the students to study in relation to their major.

This finding was also supported by the results of the questionnaires administered to the 20 students of XI-UPW class. The students were asked to fulfill the questionnaire by giving checklist whether the existing procedure text materials provided in the textbook met the needs and the purposes of the students to study in relation to their major or not.

The result from the questionnaire showed that only 3 out of 20 who thought that the first text about "How to Use the Facsimile Machine" is needed while the others considered it as unneeded material. For the other two texts, all of the students claimed that they do not need such text and they also stated that all of the texts were not related to their major. The aviation management students need the text related to aviation or it usually called the aviation English, but the book provided the text related to general thing like how to operate a machine or how to cook something.

The result also showed that one of the difficulties of the students in reading the English texts is because there were many unusual words that had no relation with their major were presented in the texts. They barely found or given a text that is related to their major.

The result of the last part of the questionnaire showed the students' expectation over the new materials. Most of the responses showed that the students' want to master both the general English and the ones related to their major. For the 
presentation, they expected the text that is featured by pictures. They want to increase their competency in English both generally and specifically as where their focus on so that, there must be equal number of both general texts and the ones related to the aviation English. It is contrary to the existing materials provided in the textbook in which none of the texts which are related to their major exists.

\section{Developing Reading Procedure Text Materials}

There were three texts in the existing materials should be developed to make it relevant with the aviation management, entitled:

- How to Use the Facsimile

- How to Make a Yummy No-bake Cheesecake

- How to Get Your Car out of the Mud

These three texts were developed by selecting procedure texts which is relevant with the students' focus. The texts were adapted from some sources such as internet and the aircraft manual's book which is handed to the airport and aircraft staff then matched it with the students' English level by simplifying the texts, deleting some sentences and provided a vocabulary lists with the meaning.

The total of the new products are five texts. Each of the text is provided by some tasks to measure the students' comprehension in reading the text. The new products can be seen on appendix G. Here are the five developed products: 


\section{Developed Procedure Texts}

\begin{tabular}{cll}
\hline No. & $\begin{array}{l}\text { Existing Procedure } \\
\text { Texts }\end{array}$ & $\begin{array}{l}\text { Developed } \\
\text { Procedure Texts }\end{array}$ \\
\hline 1. & $\begin{array}{l}\text { How to Use the } \\
\text { Facsimile Machine }\end{array}$ & $\begin{array}{l}\text { How to Check-in the } \\
\text { Carry-on Baggage }\end{array}$ \\
\hline 2. & $\begin{array}{l}\text { How to Make a Yummy } \\
\text { No-bake Cherry } \\
\text { Cheesecake }\end{array}$ & $\begin{array}{l}\text { How to Board the } \\
\text { Passenger }\end{array}$ \\
& How to Get Your Car out & $\begin{array}{l}\text { How to Evacuate } \\
\text { Aircraft Passengers } \\
\text { through Emergency } \\
\text { of the Mud }\end{array}$ \\
& & $\begin{array}{l}\text { Transit Passengers } \\
\text { Disembarkation } \\
\text { Procedure }\end{array}$ \\
\hline & & How to Fuel a Plane \\
\hline
\end{tabular}

Validating Procedure Text Materials

The developed materials were evaluated or validated by two experts to know it had been appropriate or not, they were English lecturer and the English teacher. The experts were given the questionnaires contained some aspects to assess the appropriateness of the materials, namely: linguistic, process, content, and layout. The questionnaire given was in the form of Likert-scale which consisted of five options.

The result of the validating process by the experts shows whether the developed texts are suitable for the students. They also suggested some ideas to make the developed materials appropriate both in content and visual. 
a. Validation Score from the Lecturer

The first validator was the English lecturer of English and literature department at State University of Medan, Indra Hartoyo S.Pd., M.Hum. the validation score from the lecturer is presented in the following table.

Validation Score from the Lecturer

\begin{tabular}{clcc}
\hline No. & $\begin{array}{c}\text { Criteria of } \\
\text { Validity }\end{array}$ & $\begin{array}{c}\text { Maximum } \\
\text { Score }\end{array}$ & Score \\
\hline 1. & Linguistic & $8 \times 5=40$ & 36 \\
\hline 2. & Process & $6 \times 5=30$ & 27 \\
\hline 3. & Content & $9 \times 5=45$ & 41 \\
\hline 4. & Layout & $7 \times 5=35$ & 32 \\
\hline \multicolumn{4}{r}{ Average: $\mathbf{1 3 6 / 3 0 = 4 . 5 ; ~ P e r c e n t a g e : ~} \mathbf{1 3 6 / 1 5 0} \times \mathbf{1 0 0 \% = \mathbf { 9 0 . 6 \% }}$}
\end{tabular}

Table 4.5 shows the mean $(\bar{X})$ value of the appropriateness of the developed procedure text materials for reading skill is 4.5 . It is categorized "very good" since the mean is within the interval $4.20<\bar{X} \leq 5.00$ (based on data conversion table in Chapter 3). However, there were some revisions given by the lecturer. First, in drawing the table, it could not be separated to two different pages. Second, put a clear instruction of every activity so the students will not be confused. The last he suggested to check every verb that is used and make sure it is already it the right form. 
b. Validation Score from the Teacher

The second validator was the teacher from the school the research was conducted that is SMK Manajemen Penerbangan Medan, Adelia Fadly Tanjung, S.Pd. the validation score from the teacher is presented in the following table.

Validation Score from the Teacher

\begin{tabular}{cccc}
\hline No. & $\begin{array}{c}\text { Criteria of } \\
\text { Validity }\end{array}$ & $\begin{array}{c}\text { Maximum } \\
\text { Score }\end{array}$ & Score \\
\hline 1. & Linguistic & $8 \times 5=40$ & 38 \\
\hline 2. & Process & $6 \times 5=30$ & 28 \\
\hline 3. & Content & $9 \times 5=45$ & 43 \\
\hline 4. & Layout & $7 \times 5=35$ & 34 \\
\hline \multicolumn{4}{c}{ Average: $\mathbf{1 4 3 / 3 0 = 4 . 7 ; ~ P e r c e n t a g e : ~} \mathbf{1 4 3 / 1 5 0} \times \mathbf{1 0 0 \%}=\mathbf{9 5 \%}$} \\
\hline
\end{tabular}

Table 4.6 shows the mean $(\bar{X})$ value of appropriateness of the developed procedure text materials for reading skill is 4.7 . it is categorized "Very good" since the mean is within the interval $4.20<\bar{X} \leq$ 5.00 (based on the data conversion table in Chapter 3). However, there were some suggestions given by the teacher. First, the instruction of each text is needed. The vocabulary list must add some general vocabularies, not only the words that relates with the aviation management. 
From the calculation above we can get the average score from the two experts. The average score is the score of the developed procedure text materials for reading skill.

$$
\begin{aligned}
& \bar{X} \text {. }=\frac{\text { first average score }+ \text { second average score }}{2} \\
& =\frac{4.5+4.7}{2} \\
& =\frac{9.2}{2} \\
& =4.6
\end{aligned}
$$

The average score of the developed procedure text materials for reading skill from the two experts is 4.6. it is categorized "Very good" since the mean is within the interval $4.20<\bar{X} \leq 5.00$. Based on the result, the developed procedure text materials are suitable and appropriate for the students of aviation management.

\section{Revising Materials based on Experts' Suggestion}

After validating the materials, the writer did the correction based on experts' suggestion to improve the materials' quality. The suggestions are listed as follow:

- For reading comprehension, the product doesn't need a generic structure to be explained, it would lead the materials to the writing section. 
- Recheck the verb and the imperative form of a sentence, make sure every verb use verb 1

- Make a clear instruction of what the students need to do in each activity

- The vocabulary list must not only contain the words from aviation English but also include the general words that the students may not know yet

- The figure of table must not be separated into two different pages

\section{Revised Materials based on Experts' Suggestion (Final Product)}

There were five developed reading procedure texts materials, namely: How to Check-in the Carry-on Baggage, How to Board the Passenger, How to Evacuate Aircraft Passenger through Emergency Door, and Transit Passengers Disembarkation Procedure. After revising the materials based on the expert's suggestion, the materials had been completed. Therefore, after the material validated by experts, the result showed that the materials are appropriate to be used by the eleventh grade students of aviation management.

\section{CONCLUSIONS AND SUGGESTIONS}

\section{Conclusion}

As what is stated on the background, this study was conducted because the existing materials found in the aviation management vocational school text book, specifically the procedure texts were not suitable for the students because it didn't meet the students' need as the aviation management students. The book that the 
school provided was published by the Ministry of Education and Culture, entitled "Effective Communication: An Integrated Course of English for Vocational High School 2nd year SMK". There were three procedures text found in the book, namely: How to use the Facsimile, How to make a Yummy No-bake Cheesecake, and How to Get Your Car out of the Mud. These texts were considered as irrelevant materials for the students. The aviation management students need texts that discussed about the topic related to the major.

Therefore, conducted a material development was needed to meet the students' need. The development was done through 6 steps, namely; gathering the information and data, analyzing data, developing procedure text materials, validating procedure text materials, revising the developed procedure texts by the experts, revised developed procedure texts (final product). The existing materials were developed by selecting and adapting relevant text from many sources, one of them was from the aviation basic manual. Then the selected materials were matched with the students' want to meet their expectation of what kind of book they want, such as adding pictures to make the procedure text clearer, providing the vocabulary list with the meaning, and simplifying some sentences.

After designing, the developed materials were evaluated by the experts. The average score from the experts was 4.6 which are categorized as "Very good". It means that the developed materials are appropriate and suitable to be used by the aviation management students. 
Finally, there were five reading procedure text materials related to the aviation management vocational school, entitled: How to Check-in the Carry-on Baggage, How to Board the Passenger, How to Evacuate Aircraft Passenger through Emergency Door, and Transit Passengers Disembarkation Procedure.

\section{Suggestions}

\section{Teachers}

In order to accomplish the basic competence as written in the syllabus, the teacher should consider the students' need to choose the learning materials. It could be said successful if the materials were useful for their daily life and learning environment. Developed the materials to be suitable with the students' need is needed to be conducted by the teacher. The finding of this study that is the developed reading procedure texts materials also can be applied in the school.

\section{Students}

In order to fulfill their needs, it is suggested to the students to explore other materials that is more suitable with their major from other sources.

\section{Institution}

It is suggested the school or the institution to find a proper books for the students proficiency. The institution also should consider the syllabus when choosing textbook for school which agree with the syllabus from government. 


\section{REFERENCES}

Borg, W.R \& Gall, M.D. (2003).Educational Research: An introduction. New York: Longman.

Borg, W.R \& Gall, M.D. (1985).Development Research: An introduction. New York: Longman.

Hutchinson, T. \& Waters, A. (1986).English for specific purposes. Cambridge: Cambridge University Press.

Tomlinson, B. (2013). English Language Learning Material.London.Bloomsburry Publishing. 